Open Access

\title{
Intracellular amyloid $\beta$ oligomers impair organelle transport and induce dendritic spine loss in primary neurons
}

Tomohiro Umeda 1,2, Elisa M. Ramser ${ }^{3}$, Minato Yamashita ${ }^{1}$, Koichi Nakajima ${ }^{4}$, Hiroshi Mori ${ }^{2,5}$,

Michael A. Silverman ${ }^{3^{*}}$ and Takami Tomiyama ${ }^{1,2^{*}}$

\begin{abstract}
Introduction: Synaptic dysfunction and intracellular transport defects are early events in Alzheimer's disease (AD). Extracellular amyloid $\beta(A \beta)$ oligomers cause spine alterations and impede the transport of proteins and organelles such as brain-derived neurotrophic factor (BDNF) and mitochondria that are required for synaptic function. Meanwhile, intraneuronal accumulation of $A \beta$ precedes its extracellular deposition and is also associated with synaptic dysfunction in $A D$. However, the links between intracellular $A \beta$, spine alteration, and mechanisms that support synaptic maintenance such as organelle trafficking are poorly understood.
\end{abstract}

Results: We compared the effects of wild-type and Osaka (E693 $\triangle$ )-mutant amyloid precursor proteins: the former secretes $A \beta$ into extracellular space and the latter accumulates $A \beta$ oligomers within cells. First we investigated the effects of intracellular $A \beta$ oligomers on dendritic spines in primary neurons and their tau-dependency using tau knockout neurons. We found that intracellular $A \beta$ oligomers caused a reduction in mushroom, or mature spines, independently of tau. We also found that intracellular $A \beta$ oligomers significantly impaired the intracellular transport of BDNF, mitochondria, and recycling endosomes: cargoes essential for synaptic maintenance. A reduction in BDNF transport by intracellular $A \beta$ oligomers was also observed in tau knockout neurons.

Conclusions: Our findings indicate that intracellular $A \beta$ oligomers likely contribute to early synaptic pathology in $A D$ and argue against the consensus that $A \beta$-induced spine loss and transport defects require tau.

\section{Introduction}

Synaptic dysfunction is an early event in Alzheimer's disease (AD). Soluble oligomers of amyloid $\beta(A \beta)$, which are generated from the amyloid precursor protein (APP), are believed to be the primary synaptotoxins in $\mathrm{AD}$. According to one central view of $\mathrm{AD}$ pathogenesis, extracellular $A \beta$ oligomers (eA $\beta \mathrm{Os}$ ) bind plasma membrane targets to elicit pre- and postsynaptic intracellular effects (for reviews, [1, 2]). At the postsynaptic membrane, eA $\beta O$ s interact with glutamate receptors and dysregulate calcium influx to impair long-term potentiation (LTP) and enhance long-term

\footnotetext{
*Correspondence: masilver@sfu.ca; tomi@med.osaka-cu.ac.jp

${ }^{3}$ Department of Biological Sciences, Simon Fraser University, Burnaby, British

Columbia V5A 1S6, Canada

${ }^{1}$ Department of Neuroscience, Osaka City University Graduate School of

Medicine, 1-4-3 Asahimachi, Abeno-ku, Osaka 545-8585, Japan

Full list of author information is available at the end of the article
}

depression (LTD) [3-6]. eA $\beta \mathrm{O}$ binding also alters spine morphology and decreases spine density [7, 8]. In axons, eA $\beta O s$ impair transport of cargoes such as mitochondria and vesicles containing brain-derived neurotrophic factor (BDNF) [9-11], which are both required for neuronal form and function. Mitochondria are needed at presynaptic boutons to maintain neurotransmission by producing ATP and buffering synaptic calcium $\left(\mathrm{Ca}^{2+}\right)$ [12-14]. Once secreted from axon terminals, BDNF increases spine density and the proportion of mature spines by interacting with postsynaptic TrkB receptors at the target cell membrane $[15,16]$. Thus, impaired transport of mitochondria and BDNF might contribute to synaptic dysfunction in $\mathrm{AD}[17,18]$.

Although a role for eA $\beta \mathrm{O}$ s in causing AD-like toxicity is well established, several studies have revealed that intraneuronal accumulation of $A \beta$ is also toxic 
and precedes its extracellular deposition in patients and model mice of AD [19-24]. In model mice that overexpress mutant human APP, synaptic dysfunction $[22,25]$, spine morphology alteration [26], and axonal transport defects [27] were observed in association with intracellular $A \beta$ oligomers (iA $\beta O s$ ). These pathological changes, however, may have been induced by overexpression of human APP or undetected extracellular $A \beta$. Cellular mechanisms that underlie $\mathrm{iA} \beta \mathrm{O}$-induced synaptic dysfunction remain uncharacterized. Furthermore, although it is widely reported that tau is required for eA $\beta \mathrm{O}$ toxicity (for a review, [28]), whether iA $\beta O$ toxicity is tau-dependent has not yet been investigated.

A valuable model for studying $\mathrm{iA} \beta \mathrm{O}$ s is an APP mutation identified in familial AD. The Osaka $(\mathrm{E} 693 \Delta)$ mutation in APP induces iA $\beta O$ accumulation without detection of $A \beta$ fibrillization in vitro and without detectable $A \beta$ plaque formation in $A D$ patients or mouse models [29-31]. Intracellularly, the Osaka mutation-induced iA $\beta O$ s lead to endoplasmic reticulum stress and damage of mitochondria and organelles within the endosomal/lysosomal system [32].

Here, we determined and compared the effects of wild-type APP $\left(\mathrm{APP}_{\mathrm{WT}}\right)$ and Osaka-mutant APP $\left(\mathrm{APP}_{\mathrm{OSK}}\right)$ on dendritic spine morphology and intracellular transport of organelles required for synaptic maintenance and function. We found that $\mathrm{iA} \beta \mathrm{O}$ s reduced the number of mature spines and impaired transport of BDNF, mitochondria, and recycling endosomes in hippocampal neurons expressing

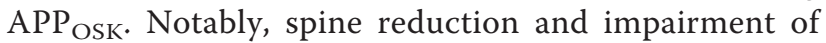
BDNF transport occurs independently of tau. These results advance our understanding of early AD synaptic pathology because iA $\beta O$ accumulation precedes extracellular amyloid deposition in patients and $\mathrm{AD}$ model mice. Our findings may promote development of effective therapeutic compounds for AD prevention and treatment.

\section{Materials and methods}

\section{Preparation of primary neurons}

Mouse primary neurons were prepared from embryos of wild-type $(M A P T+/+)$ and tau knockout $(M A P T-/-)$ mice (Jackson Laboratory, Bar Harbor, ME) at embryonic day 18 (E18). Hippocampal tissues were dissected in icecold Hank's balanced salt solution (HBSS; Sigma-Aldrich, St. Louis, MO) and incubated in $1 \mathrm{ml}$ of papain solution ( $2 \mathrm{mg} / \mathrm{ml}$ in HBSS) at $37^{\circ} \mathrm{C}$ for $30 \mathrm{~min}$ with gentle mixing. After being washed with $5 \mathrm{ml}$ of $50 \%$ horse serum in HBSS once, $5 \mathrm{ml}$ of HBSS twice, and $4 \mathrm{ml}$ of neuronal culture medium (Neurobasal, Electro medium supplemented with B27, Electro and $500 \mu \mathrm{M}$ L-glutamine; all from
GIBCO, Life Technologies, Carlsbad, CA) once, the tissues were dissociated into cells by pipetting several times with a Pasteur pipet in $2 \mathrm{ml}$ of neuronal culture medium. The cell suspensions were plated onto poly-Llysine-coated coverslips in 6-well culture plates at a density of 170,000 cells $/ 2 \mathrm{ml} /$ well. For transport analyses, primary neurons from wild-type and tau knockout mice, and wild-type rats were prepared from embryos at E16 and E18, respectively, as described [33]. Neurons were cultured on coverslips in Neurobasal medium supplemented with B27 at a density of 250,000 cells $/ 5 \mathrm{ml}$ in $6 \mathrm{~cm}$ dishes. The astrocyte feeder layer for the neuronal co-culture was generated using neural progenitor cells as described previously [34].

\section{Expression vectors}

The pCI-APP construct was prepared using a $\mathrm{pCI}$ vector (Promega, Madison, WI) as described previously [29]. A pEGFP (enhanced green fluorescent protein)-N2 vector was obtained from Clontech (Takara Bio Inc. Otsu, Japan). The pIRES2-APP-EGFP vectors were made by amplifying $\mathrm{APP}_{\mathrm{WT}}$ and $\mathrm{APP}_{\mathrm{OSK}}$ using a forward primer containing an Nhe I restriction site (underlined) 5'AATTAATTAAGCTAGCGCCACCATGGGGGCTGC CCGGTTTGGCACTGCT-3' and a reverse primer containing a Sac II restriction site 5'- TTAATTAATTCCGCGGCTAGTTCTGCATCTGCTCAAAGAACTTGTAGGTTGG-3' for subcloning into pIRES2-EGFP (Takara Clontech Bio Inc. Otsu, Japan). Plasmid composition was confirmed by sequencing. The $\mathrm{p} \beta$-actin-BDNF-mRFP (monomeric red fluorescent protein) and $\mathrm{p} \beta$-actin-eBFP (enhanced blue fluorescent protein) vectors were a kind gift from Dr. G. Banker (Oregon Health and Sciences University). The pcDNA3 Mt-eYFP (enhanced yellow fluorescent protein) construct was designed to express the COX IV mitochondrial-targeting sequence-EYFP fusion proteins and kindly gifted from Dr. G. Rintoul (Simon Fraser University). The JPA5-TfR -GFP vector is described in Burack et al. [35].

\section{Analyses of APP expression}

Mouse primary neurons were cultured for 21 days in vitro. The cells were cotransfected with pCI-APP $\left(\mathrm{APP}_{\mathrm{WT}}, \mathrm{APP}_{\mathrm{OSK}}\right.$, or empty) and pEGFP-N2 using a Lipofectamine2000 reagent (Invitrogen, Life Technologies). Transfection was performed in the presence of $0.5 \mu \mathrm{M}$ kynurenic acid (Sigma-Aldrich) to lessen excitotoxic cell damage. Cells expressed the transgenes for 2 days. For immunocytochemical analysis of APP expression, the cells were fixed with $4 \%$ paraformaldehyde in PBS at room temperature for $30 \mathrm{~min}$ and permeabilized by immersion in $0.05 \%$ Tween-20 in PBS for a moment. After a brief 
wash, the cells were blocked with $20 \%$ calf serum in PBS at room temperature for $1 \mathrm{~h}$. The cells were then stained with human APP-specific antibody 6E10 (Covance, Berkeley, CA) or A $\beta$ oligomer-specific antibody 11A1 (IBL, Fujioka, Japan) at room temperature for $1 \mathrm{~h}$ followed by Rhodamine-conjugated anti-mouse IgG antibody (Jackson ImmunoResearch Labs, West Grove, PA) at room temperature for $20 \mathrm{~min}$. The stained specimens were mounted with VECTASHIELD mounting medium with DAPI (H-1500; Vector Laboratories, Burlingame, CA) and viewed under a Leica TCS SP5 confocal laser microscope (Leica, Wetzlar, germany). For Western blot analysis of APP expression, the cells were lysed in $1 \%$ Triton X-100/Tris-buffered saline $(100 \mathrm{mM}$ Tris- $\mathrm{HCl}, \mathrm{pH} 7.6,150 \mathrm{mM} \mathrm{NaCl}$ ) containing protease inhibitor cocktail P8340 (Sigma-Aldrich). The lysates were separated by SDS-PAGE and transferred onto polyvinylidene difluoride membranes. Human APP and actin were stained with 6E10 and rabbit anti-actin antibody (SigmaAldrich) followed by horseradish peroxidase-conjugated secondary antibodies and chemiluminescent peroxidase substrate (Millipore, Billerica, MA). Signals were visualized and quantified using a LAS-3000 luminescent image analyzer (Fujifilm, Tokyo, Japan).

\section{Analyses of dendritic spines}

Mouse primary neurons transfected with pCI-APP and pEGFP-N2 were fixed with $4 \%$ paraformaldehyde after a 2-day culture. The fixed cells were mounted, and the images were taken using a Leica TCS SP5 confocal laser microscope. Dendritic spines were classified into four groups by the criteria as follows: mushroom, the length $\leq 5 \mu \mathrm{m}$ and the ratio of neck width/head width $\geq 1.5$; stubby, the length $\leq$ $1 \mu \mathrm{m}$ and the ratio of neck width/head width $<1.5$; thin, $1<$ the length $\leq 5 \mu \mathrm{m}$ and the ratio of neck width/head width $<1.5$; and fillopodia, the length $\geq$ $1.5 \mu \mathrm{m}$ without a head [36, 37]. Three to seven independent cultures were made for each $\mathrm{APP}_{\mathrm{WT}^{-}}$, $\mathrm{APP}_{\mathrm{OSK}^{-}}$, and mock transfection. One transfected cell was chosen from each culture and analyzed for spines with 3 to 12 dendrites per cell.

To study the effects of extracellular $A \beta$ on spines, we first determined the levels of $A \beta$ secreted from cells into culture media. Culture media of mouse primary neurons transfected with pCI-APP were harvested 2 days after transfection. $A \beta$ concentrations in the media were measured using a human/mouse A 340 ELISA kit (Wako Pure Chemical Industries, Osaka, Japan). Then, mouse primary neurons transfected with pEGFP-N2 alone (without pCI-APP) were cultured for 2 days in the presence of synthetic wildtype $A \beta 42$ or Osaka (E22 $\triangle$ )-mutant $A \beta 42$ (41 amino acids) peptide (both from Peptide Institute, Mino,
Japan) at various concentrations. After cell fixation, dendritic spines were analyzed as described above.

\section{Analyses of axonal and dendritic transport}

Mouse and rat primary neurons were cultured for 10-12 days in vitro. For analysis of BDNF transport, mouse primary neurons were doubly transfected with pIRES2-APP-EGFP and $\mathrm{p} \beta$-actin-BDNF-mRFP. For analysis of mitochondria transport, rat primary neurons were triply transfected with pCI-APP, pcDNA3 Mt-eYFP, and pmUBa-eBFP. To analyze recycling endosome transport, we chose the transferrin receptor (TfR) as a marker for recycling endosomes and used pCI-APP, JPA5-TfR-GFP, and pmUBa-eBFP in transfection of rat primary neurons. The soluble GFP and BFP are distributed throughout the cell body and processes enabling us to determine the orientation of the cell body relative to the axon, thus, distinguishing anterograde and retrograde transport. All transfections were done in the presence of $0.5 \mu \mathrm{M}$ kynurenic acid as described above. Two days after transfection, $\mathrm{BDNF} /$ mitochondria/TfR transport was analyzed using a standard wide-field fluorescence microscope equipped with a cooled charge-coupled device camera and controlled by MetaMorph (Molecular Devices, Sunnyvale, CA) according to Kwinter et al. [38]. BDNF imaging was recorded by the "stream acquisition module", and mitochondria and TfR imaging were recorded by the "acquire timelapse module" in MetaMorph. Briefly, cells were sealed in a heated imaging chamber, and streaming recordings of BDNF were acquired from triple transfectants for $25 \mathrm{~s}$ (250-msec exposures). Frames were captured continuously for $300 \mathrm{~s}$ (400-msec exposures) for mitochondria transport and $100 \mathrm{~s}$ (500msec exposures) for TfR transport. This captured dozens of transport events per cell in $100-\mu \mathrm{m}$ segments of the axon and $45-\mu \mathrm{m}$ segments of the dendrite. Axons and dendrites were initially identified based on morphology and confirmed retrospectively by immunostaining MAP2, a dendrite-specific microtubule-associated protein, with mouse anti-MAP2 antibody (Millipore). Vesicle flux was obtained through tracing kymographs in MetaMorph. Vesicle flux was defined as the total distance traveled by vesicles standardized by the length and duration of each movie (in micron-minutes): $\sum_{i=1}^{n} d_{i} /(\ell \times t)$, where $d$ is the individual vesicle run lengths, $\ell$ is the length of axon or dendrite observed, and $t$ is the duration of the observation [38].

\section{Statistical analyses}

All values obtained are expressed as the mean \pm SEM. Comparisons of means among multiple groups were performed using Fisher's PLSD test following 
ANOVA. Differences with a $p$ value of $<0.05$ were considered significant.

\section{Results}

Dendritic spines are altered in neurons accumulating $\mathrm{i} A \beta \mathrm{O}$ Spines are generally classified into four types based on the shape: stubby (type-I), mushroom (type-II), thin (type-III), and filopodia-like protrusions. Mushroom spines are stable and represent mature synapses, while thin spines are transient and maintain structural plasticity [39]. Stubby spines are thought to be immature, and filopodia-like protrusions lack synapses [39]. Due to the reduction in synapses found in $\mathrm{AD}$ brains, we asked if there is a change in the density and morphology of dendritic spines in APP expressing neurons. Mouse primary neurons were transfected with two plasmid vectors to simultaneously express APP and GFP, the latter was introduced to visualize spines. By staining cells with human APP-specific 6E10 antibody, we confirmed that all GFP-positive neurons expressed human APP (Fig. 1a). Western blot analysis with the 6E10 antibody indicated no significant difference in the levels of human APP expression between $\mathrm{APP}_{\mathrm{WT}^{-}}$and $\mathrm{APP}_{\mathrm{OSK}^{-}}$-transfectants (Fig. $1 \mathrm{~b}$ and c). Importantly, only $\mathrm{APP}_{\mathrm{OsK}}$-expressing
A
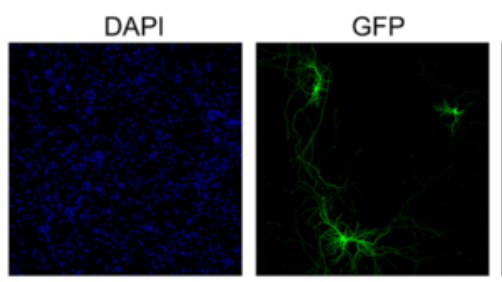

B
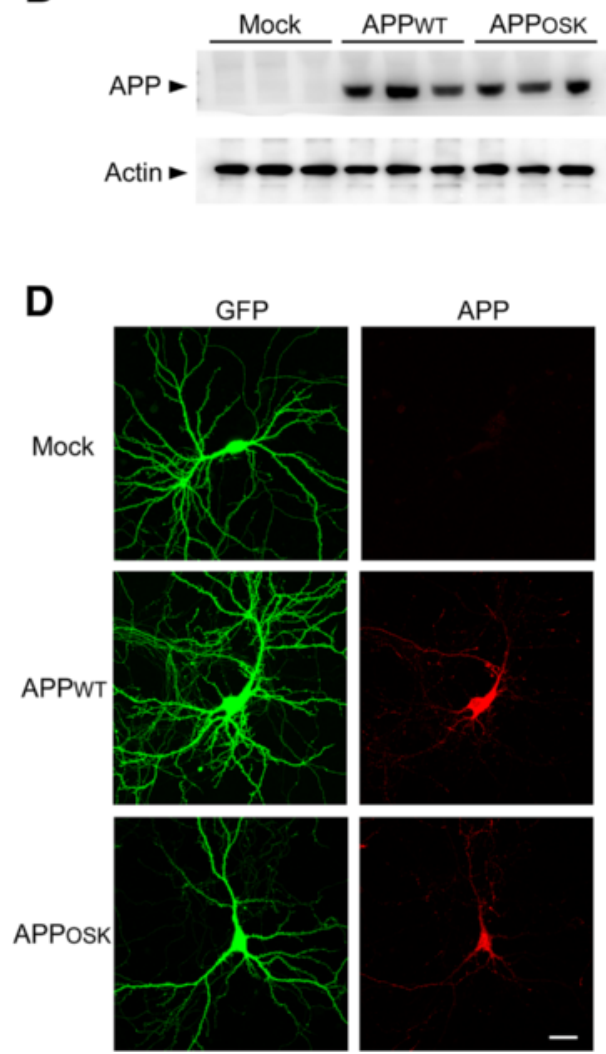

APP
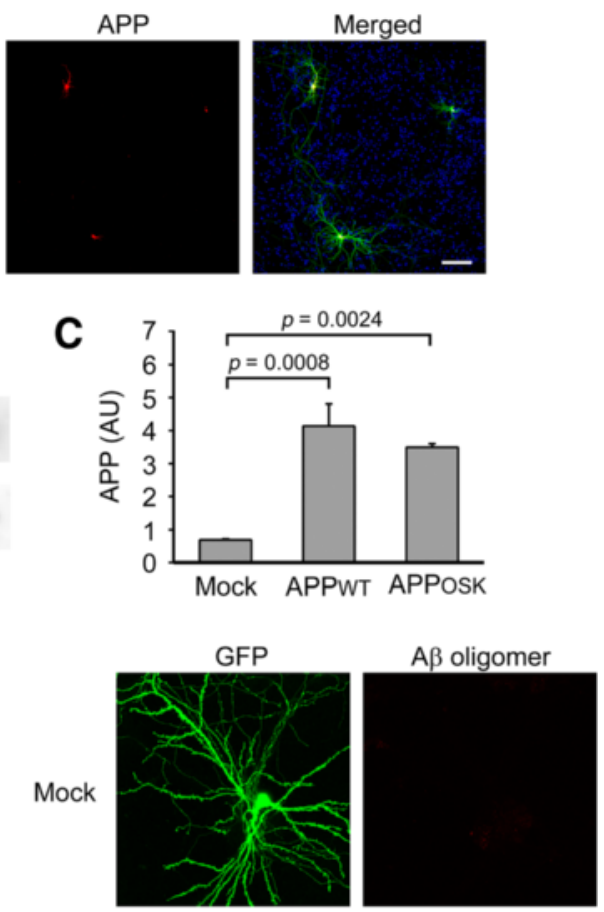

APPWT
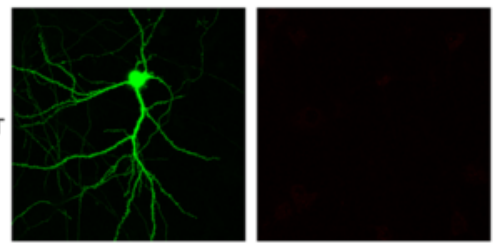

APPOSK
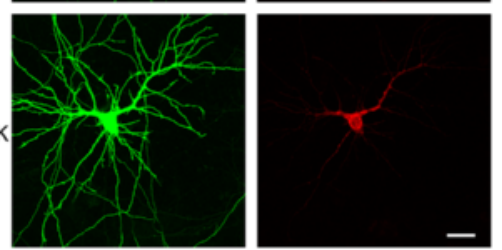

Fig. 1 APP expression and A $\beta$ oligomer accumulation in APP-transfected neurons. Mouse primary neurons were transfected with two plasmid vectors to simultaneously express APP and GFP. a Cells were stained with DAPI and human APP-specific 6E10 antibody (red). All GFP-positive neurons expressed human APP. Scale bar, $200 \mu \mathrm{m}$. b Cell homogenates were subjected to Western blot with 6 E10 and anti-actin antibodies. c No significant difference in the levels of human APP expression between APP TT $^{-}$and APPosk-transfectants. AU, arbitrary unit. d Cells were stained with 6 E10 (red) or A oligomer-specific 11A1 antibody (red). Only APP osk-expressing neurons accumulated abundant iA 30 s. Scale bar, $30 \mu \mathrm{m}$ 
neurons accumulated abundant $\mathrm{iA} \beta \mathrm{O}$, which were visualized by staining with the $\mathrm{A} \beta$ oligomer-specific $11 \mathrm{~A} 1$ antibody (Fig. 1d). We classified individual spines on dendrites of GFP-positive neurons into the four types, and compared the numbers of total and each type spines among $\mathrm{APP}_{\mathrm{OsK}^{-}}$-expressing, $\mathrm{APP}_{\mathrm{WT}}$-expressing, and mock-transfected neurons (Fig. 2). Compared with mock-transfectants, $\mathrm{APP}_{\mathrm{WT}}$-expressing cells showed a small increase in the number of total and mushroomtype spines with no significant changes in other types. In contrast, $\mathrm{APP}_{\mathrm{OSK}^{-}}$-expressing cells exhibited a significant reduction in the number of total and mushroom-type spines, but no significant changes in other types. Taken together, these results suggest that the accumulation of iA $\beta$ Os markedly decreases spine density, particularly the mature mushroom-type spines.
Spine reduction is not a result of extracellular $A \beta$

Altered spine density and morphology may have been induced by extracellular $A \beta$ secreted from cells. To test this possibility, we first measured the levels of $A \beta$ in the culture media using a human/mouse A $\beta 40$ ELISA kit. The culture media of mock-, $\mathrm{APP}_{\mathrm{WT}^{-}}$, and $\mathrm{APP}_{\mathrm{OSK}^{-}}$ transfectants contained about $89.5 \pm 17.1,183.5 \pm 15.1$, and $63.8 \pm 4.5 \mathrm{pM}$ of $\mathrm{A} \beta 40$, respectively. This is consistent with our previous finding that the Osaka mutation reduced $A \beta$ secretion [30].

Subsequently we added synthetic A $\beta 42$ peptide into culture media of GFP-expressing neurons at various concentrations. Before adding the peptides, we examined $A \beta$ oligomer formation in the peptide solutions by Western blot using the 6E10 antibody. Wild-type A 342 peptide showed mainly monomers and with a faint signal for
A
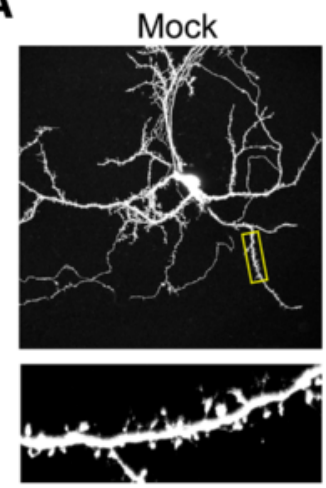

B

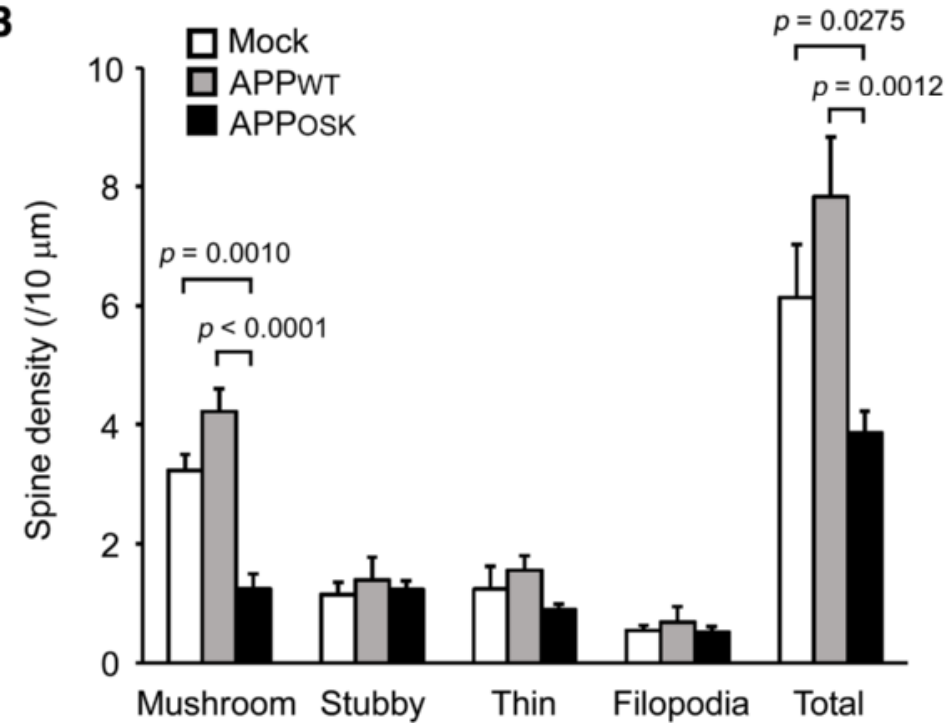

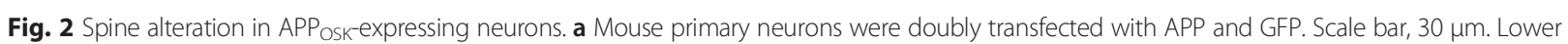
panels, enlarged views of the dendrites surrounded with a square. $\mathbf{b}$ Individual spines on dendrites of GFP-positive neurons were classified into the four types: mushroom, stubby, thin, and filopodia-like protrusions. Compared with mock-transfectants, APPWT-expressing cells showed a small increase the number of total and mushroom-type spines with no significant changes in other types. In contrast, APP osk-expressing cells exhibited a significant reduction in the number of total and mushroom-type spines, but no significant changes in other types 
dimers, whereas the Osaka-mutant $\mathrm{A} \beta 42$ peptide exhibited abundant monomers as well as dimers, trimers, tetramers, and 12-mers (Fig. 3a). After $48 \mathrm{~h}$ exposure to $A \beta$ peptides, spine densities and types were measured in primary neurons. Unexpectedly, wild-type $A \beta 42$ peptide increased total and mushroom-type spines at physiological, low concentrations (100 pM to 400 pM; Fig. 3b) [40, 41]. However, such a trophic effect was attenuated at concentrations over $1 \mathrm{nM}$. At $25 \mathrm{nM}$, wild-type peptide significantly decreased total and mushroom-type spines. In contrast, the Osaka-mutant $\mathrm{A} \beta 42$ peptide did not affect spine morphology at low concentrations (100 pM $-400 \mathrm{pM})$, yet significantly decreased total and mushroom-type spines at higher concentrations over $1 \mathrm{nM}$ (Fig. 3c). These results are consistent with our previous observation that wild-type, but not Osaka-mutant, A $\beta 42$ peptide showed a trophic effect on synaptophysin levels in cultured mouse hippocampal slices [42]. The present result with wild-type $A \beta$ peptide
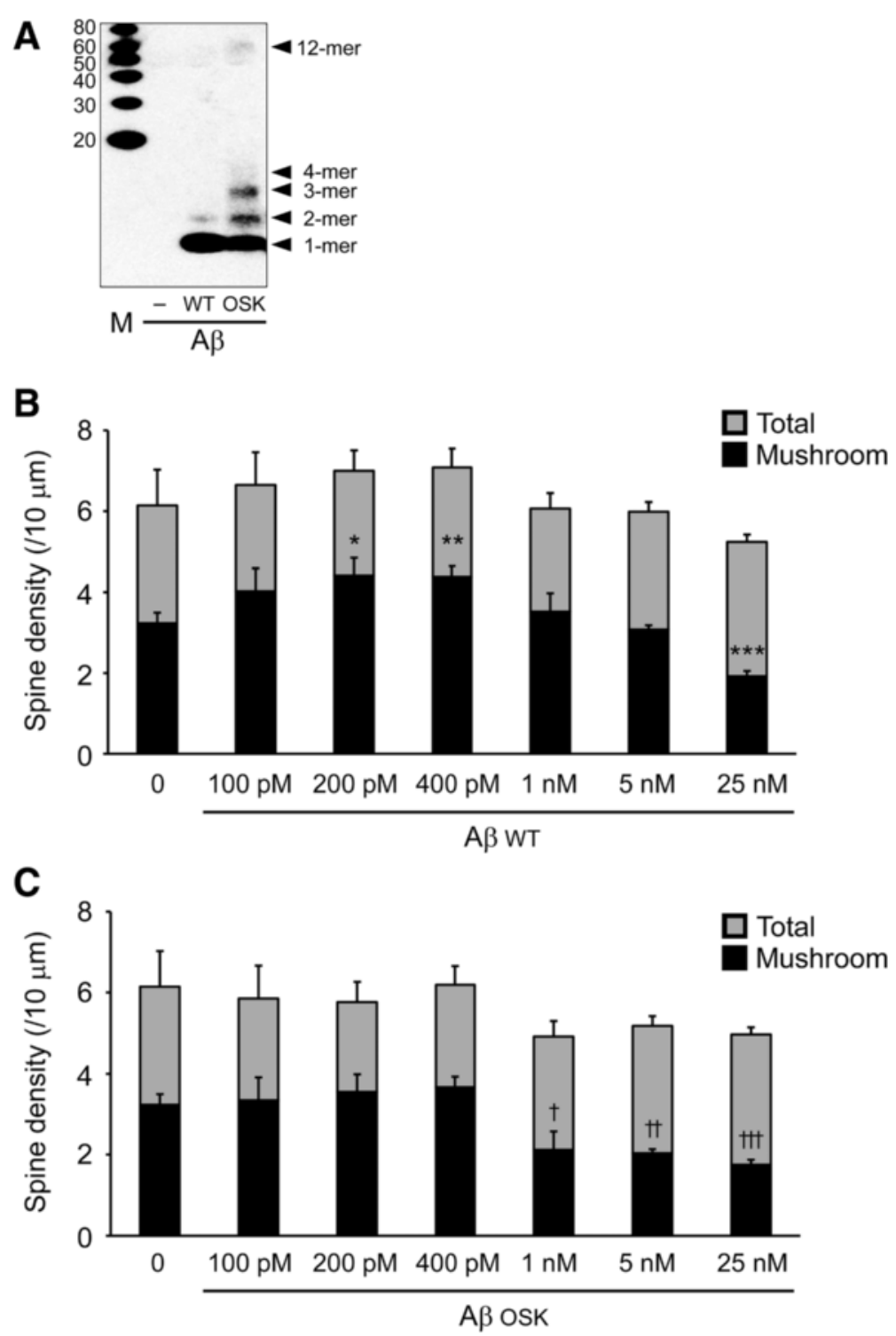

Fig. 3 Effects of extracellular A $\mathrm{B}$ on spines. Synthetic wild-type (WT) or Osaka-mutant (OSK) A 42 peptides were added into culture media of GFP-expressing neurons at various concentrations. a Before adding the peptides, A $\beta$ oligomer formation in the peptide solutions were examined by Western blot with 6E10 antibody. A $\beta$ WT peptide showed mainly monomers and faintly dimers, whereas A 3 OSK peptide exhibited abundant monomers as well as dimers and trimers and faintly tetramers and 12-mers. b, c After a 2-day culture in the presence of $A \beta$ peptides, spine densities and types were measured. $A \beta W T$ peptide (b) increased total and mushroom-type spines at physiological, low concentrations from $100 \mathrm{pM}$ to $400 \mathrm{pM}$. In contrast, A OSK peptide (c) did not affect spine morphology at those concentrations. However, both $A \beta W T$ and $A \beta$ OSK peptides significantly decreased total and mushroom-type spines at higher concentrations: at $25 \mathrm{nM}$ of $A \beta$ WT peptide and over $1 \mathrm{nM}$ of $A \beta$ OSK peptide 
A
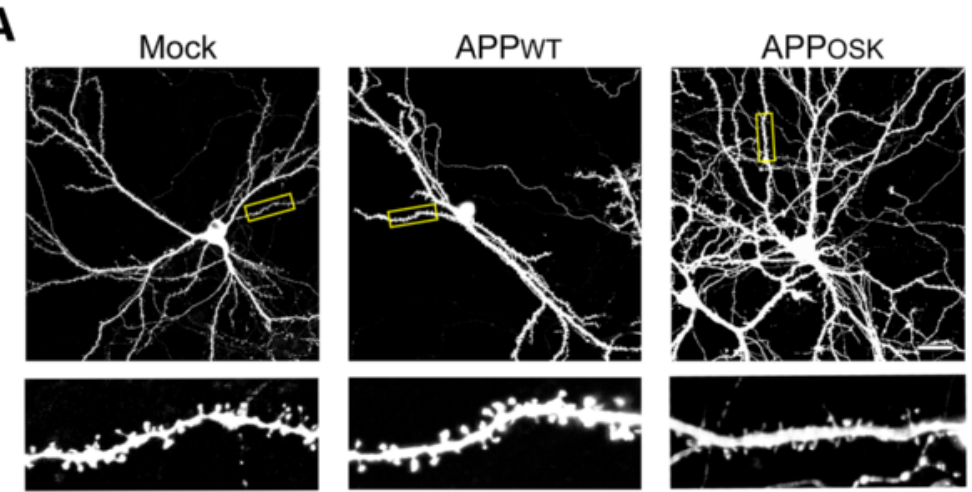

B

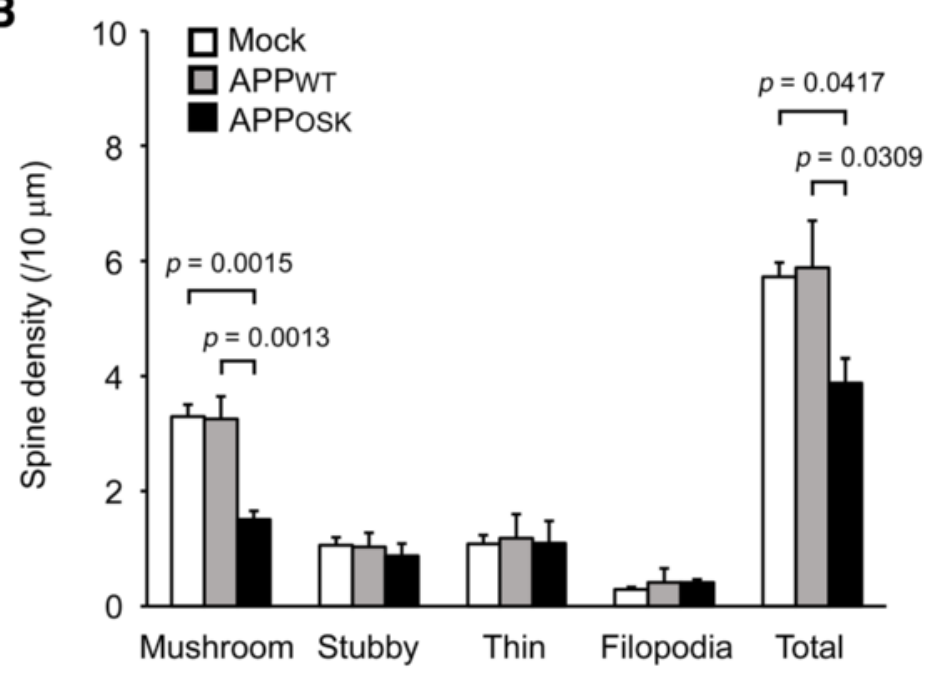

C

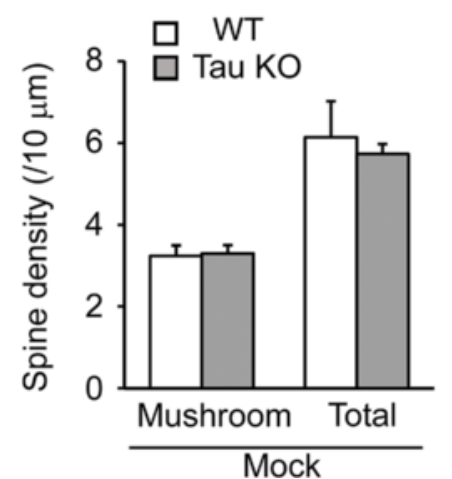

D

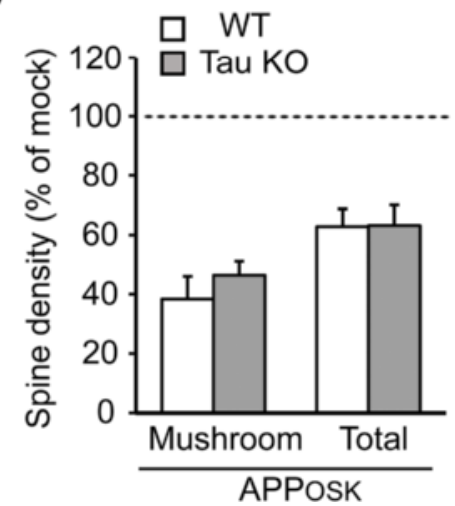

Fig. 4 Spine alteration in APPosk-expressing tau knockout neurons. a Primary neurons were prepared from tau knockout mice and doubly transfected with APP and GFP. Scale bar, $30 \mu \mathrm{m}$. Lower panels, enlarged views of the dendrites surrounded with a square. $\mathbf{b}$ Spine

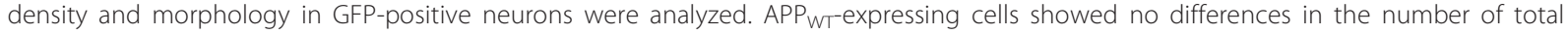
and each type spine compared to mock-transfectants. In contrast, APPosk-expressing cells exhibited a significant reduction in the number of total and mushroom-type spines with no significant changes in other types. c, d Comparison of spine alteration between wild-type (Fig. 2) and tau knockout neurons expressing APPosk. c There were no differences in the density of mushroom-type and total spines between wild-type and tau knockout neurons. d APPosk expression reduced the spine density in both wild-type and tau knockout neurons: No differences in the reduction of mushroom-type $(p=0.4835)$ and total spines $(p=0.9702)$ between these neurons 
implies that the increase in total and mushroom-type spines observed in $\mathrm{APP}_{\mathrm{WT}}$-expressing neurons (Fig. 2) might be induced by extracellular $A \beta$ secreted from the cells. On the contrary, the result with the Osaka-mutant $A \beta$ peptide suggests that the spine alterations observed in $\mathrm{APP}_{\mathrm{OSK}^{-}}$-expressing neurons (Fig. 2) could be attributed to iA $\beta$ Os.

\section{iA $\beta O$-induced spine alteration is independent of tau}

Whether extracellular $A \beta$ requires tau to mediate changes in postsynaptic structure remain a topic of debate. One model suggests that postsynaptic defects occur upstream of significant changes in tau phosphorylation [43], yet recent studies indicate tau hyperphosphorylation and mislocalization leads to postsynaptic deficits [44-46]. However, it is unknown if tau is required for $\mathrm{iA} \beta \mathrm{O}$ s to exhibit toxic effect on spines. Primary neurons were prepared from tau knockout mice and doubly transfected with APP and GFP. We confirmed again that all GFP-positive neurons expressed human APP and that only $\mathrm{APP}_{\mathrm{OSK}}$-expressing neurons accumulated abundant iA $\beta$ Os (data not shown). Similar to the experiments in wild-type neurons we analyzed spine density and morphology in GFP-positive neurons. APP $\mathrm{WT}_{\text {-expressing }}$
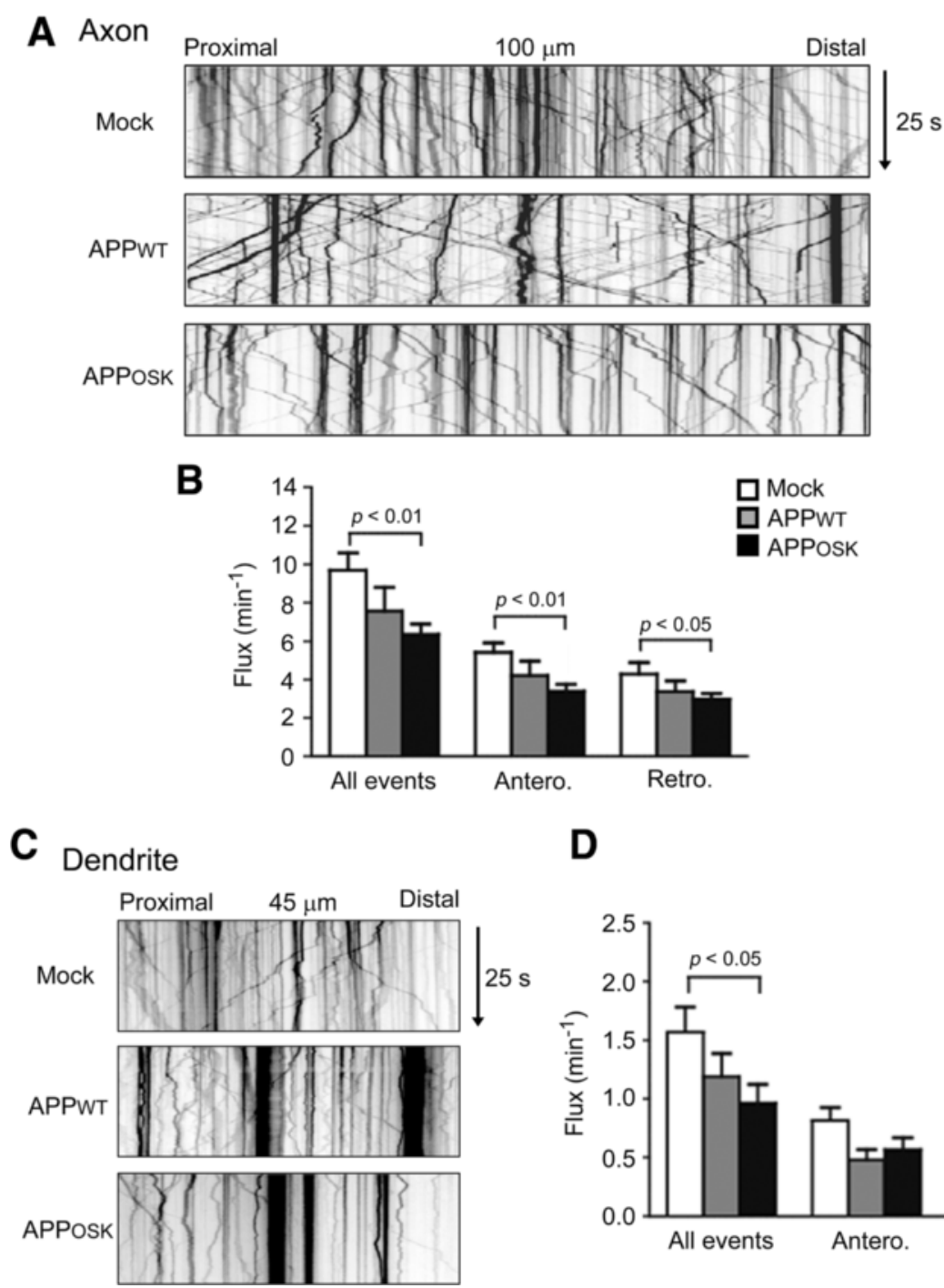

D

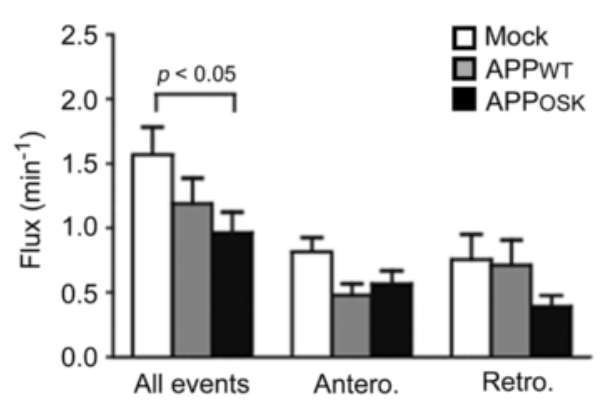

Fig. 5 Axonal and dendritic transport of BDNF is impaired in APPosk-expressing neurons. Wild-type mouse primary neurons were doubly transfected with APP-EGFP and BDNF-mRFP. Transport of BDNF in living neurons was recorded for $25 \mathrm{~s}$, and those in 100- $\mu \mathrm{m}$ segments of the axon (a) and 45- $\mu \mathrm{m}$ segments of the dendrite (c) were analyzed. Axons and dendrites were initially identified based on morphology and confirmed retrospectively by immunostaining MAP2. $\mathbf{b}$ Compared with mock-transfectants, both APP WT $_{\text {- and APP }}$ osk-expressing cells showed a decrease of bidirectional transport of BDNF in axons, but the differences were significant only in APPosk-expressing cells. $\mathbf{d}$ Similarly, a decrease of bidirectional transport of BDNF in dendrites was observed in both $\mathrm{APP}_{\mathrm{WT}^{-}}$and $\mathrm{APP}_{\mathrm{OSk}}$-expressing cells, but significant reduction was observed only for total event in

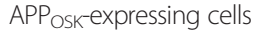


cells showed no differences in the number of total spines and morphologically distinct spines compared to mocktransfectants (Fig. 4a, b). The trophic effect of $\mathrm{APP}_{\mathrm{WT}}$ expression on total and mushroom-type spines was not seen in tau knockout neurons. In contrast, $\mathrm{APP}_{\mathrm{OSK}^{-}} \mathrm{ex}-$ pressing cells exhibited a significant reduction in the number of total and mushroom-type spines with no significant changes in other types. Finally, we observed no significant differences in spine alteration between wild-type and tau knockout neurons expressing $\mathrm{APP}_{\mathrm{OSK}}$ (Fig. 4c, d). These results indicate that $\mathrm{iA} \beta \mathrm{O}$-induced spine alteration is independent of tau.
iA $\beta O$ s disrupt axonal and dendritic transport of BDNF

What is the cellular mechanism underlying the spine alterations caused by iA $\beta$ Os? Notably, BDNF is known to increase spine density and the proportion of mature spines. Furthermore, reduced levels of BDNF correlate with $\mathrm{AD}$ progression $[17,47]$. We speculated that $\mathrm{iA} \beta \mathrm{O}$ disrupt vesicular transport of BDNF to sites of release in axons and dendrites, thereby inducing spine alteration.

To test this hypothesis, we analyzed axonal and dendritic transport of BDNF in living neurons. Wild-type mouse primary neurons were transfected with APPEGFP and BDNF-mRFP. After video recording, neurons

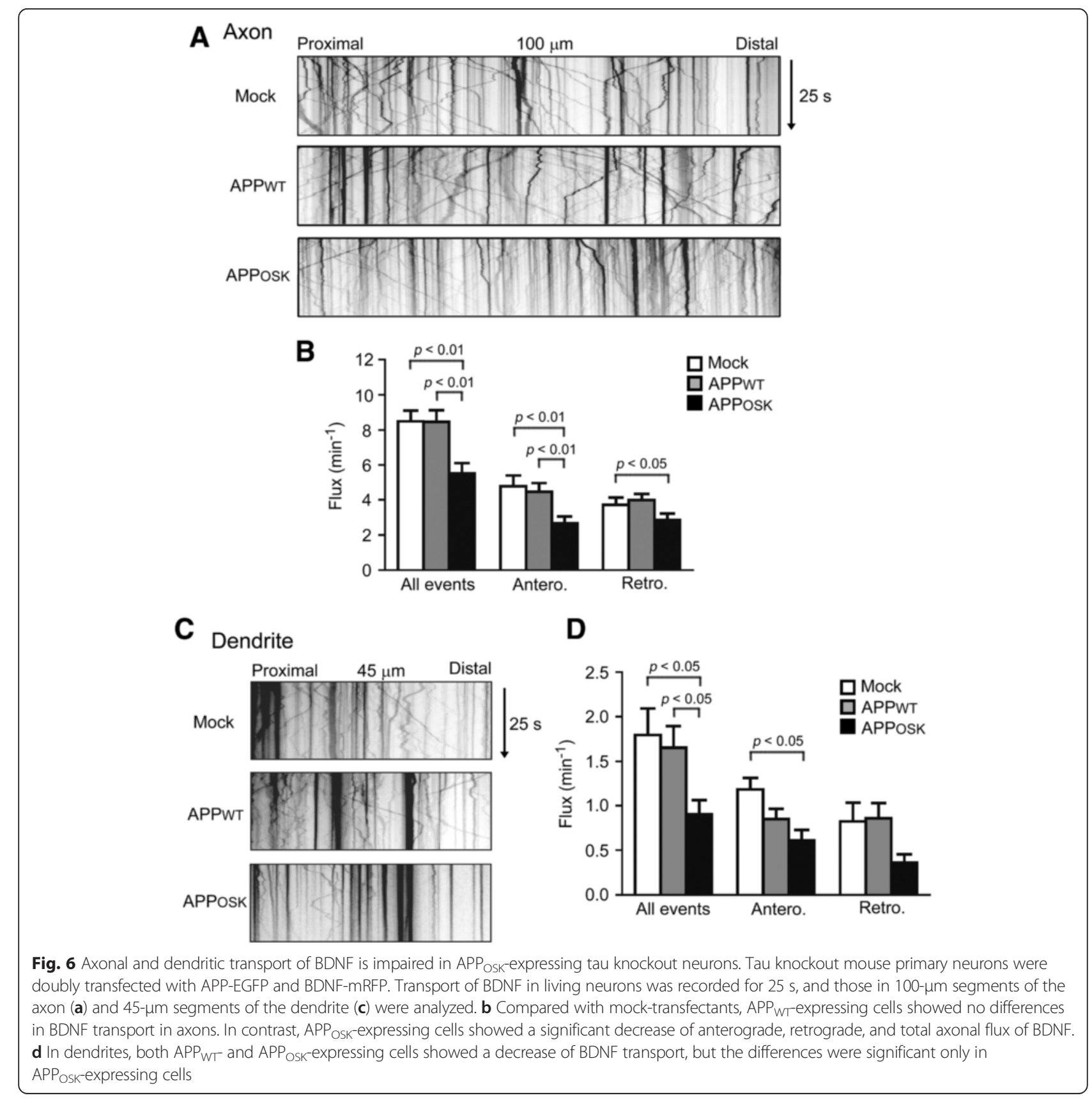




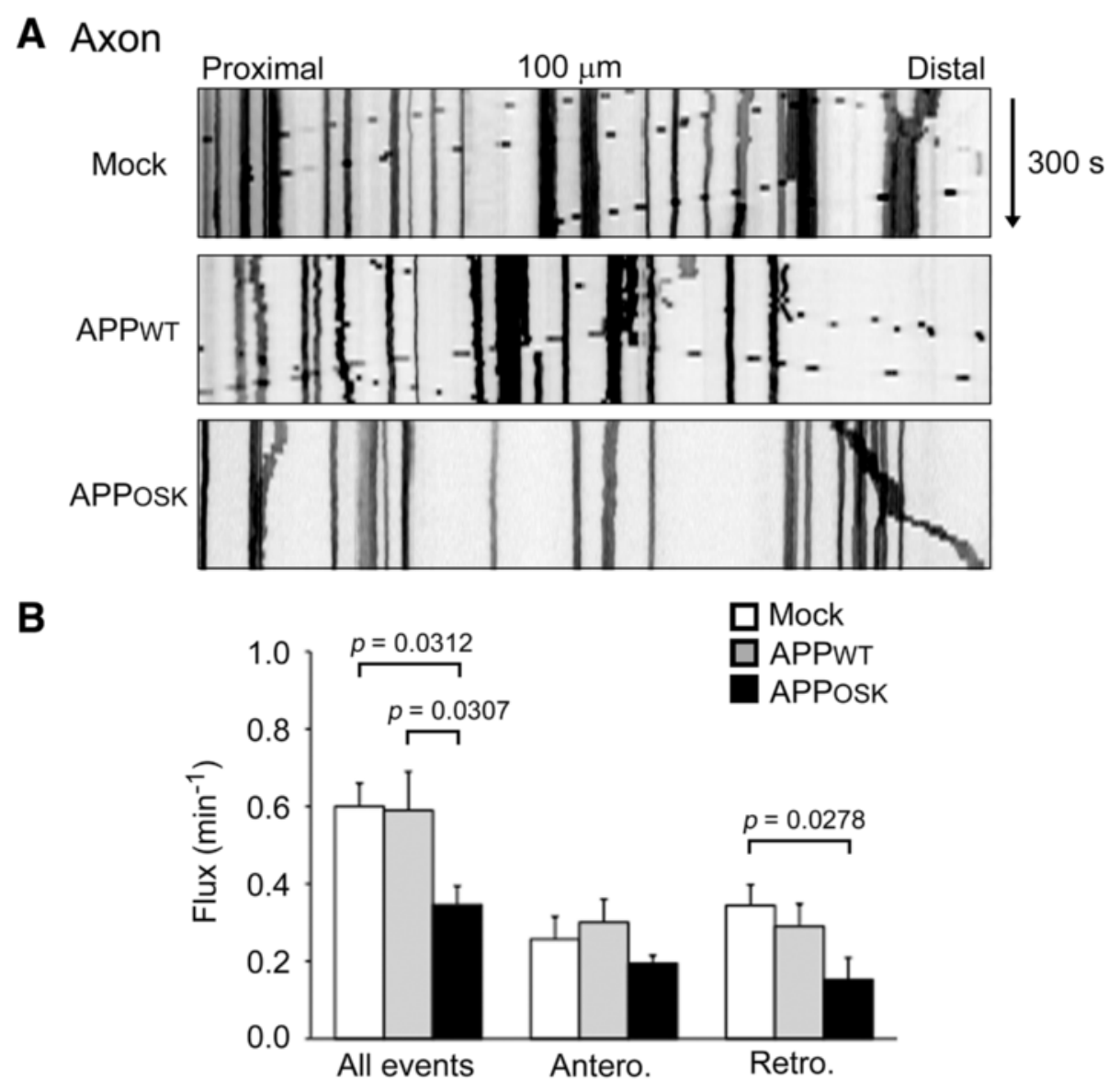

\section{Dendrite}
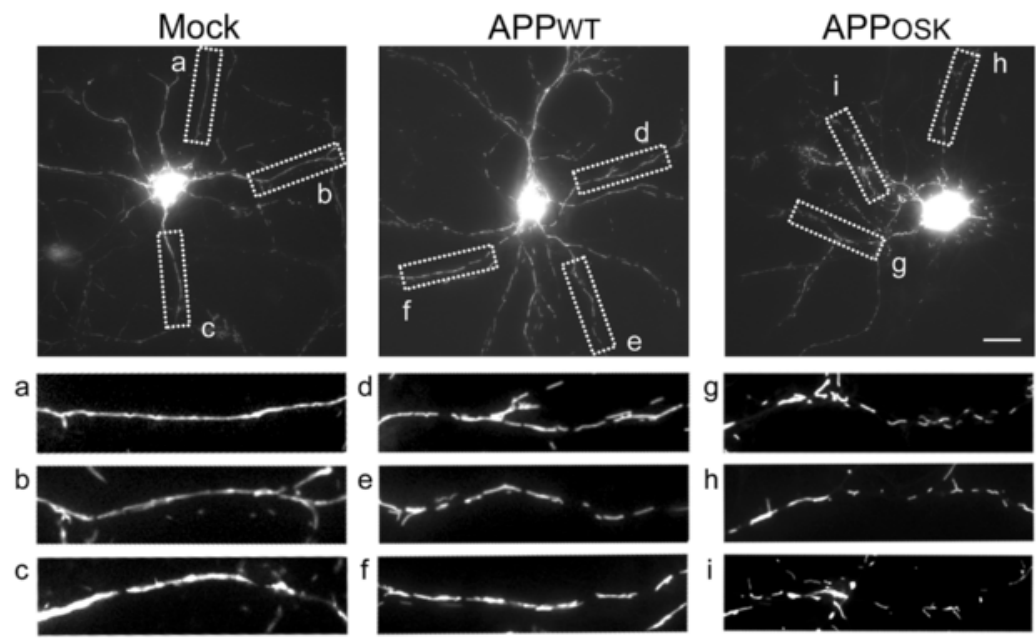

Fig. 7 Impaired axonal transport and aberrant dendritic distribution of mitochondria in APPosk-expressing neurons. Rat primary neurons were triply transfected with APP, Mt-eYFP, and BFP. a Transport of mitochondria in living neurons was recorded for $300 \mathrm{~s}$, and those in $100-\mu \mathrm{m}$ segments of the axon were analyzed. $\mathbf{b}$ Compared with mock-transfectants, bidirectional transport of mitochondria in axons was reduced in $\mathrm{APP}_{\mathrm{OSK}^{-}}$, but not $\mathrm{APP}_{\mathrm{WT}^{-}}$, expressing cells. $\mathbf{c}$ In dendrites, mitochondria were evenly distributed along the dendritic shafts in

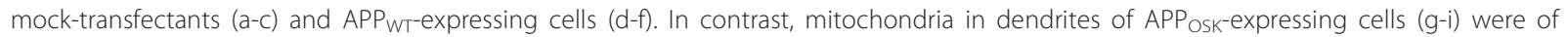
shorter length and unevenly distributed. Scale bar, $20 \mu \mathrm{m}$ 
were fixed and stained with an antibody to MAP2, a dendrite-specific microtubule-associated protein, to distinguish dendrites from axons. Compared with mocktransfectants, both $\mathrm{APP}_{\mathrm{WT}^{-}}$and $\mathrm{APP}_{\mathrm{OSK}^{-}}$-expressing cells showed a decrease of anterograde, retrograde, and total axonal flux of BDNF, but the differences were significant only in $\mathrm{APP}_{\mathrm{OSK}^{-}}$-expressing cells (Fig. 5a, b; flux is an index of transport described in the Materials and Methods). Similar results were obtained in dendrites: A decrease in bidirectional transport of BDNF was observed in both $\mathrm{APP}_{\mathrm{WT}^{-}}$and $\mathrm{APP}_{\mathrm{OSK}^{-}}$-expressing neurons, but significant reduction was observed only for total transport in $\mathrm{APP}_{\mathrm{OSK}}$-expressing neurons (Fig. 5c, d). These results support our speculation that $\mathrm{iA} \beta \mathrm{O}$ s cause spine alterations via the blockade of BDNF transport that is required to supply sites of release.

\section{iA $\beta O$ s disrupt axonal and dendritic transport of BDNF independent of tau}

We showed that $\mathrm{iA} \beta \mathrm{O}$-induced spine alteration is independent of tau (Fig 4), but it is unknown if this tauindependence extends to other cellular mechanisms such as intracellular transport. To determine if $\mathrm{iA} \beta \mathrm{O}$-induced BDNF transport defects are tau independent, we analyzed transport of BDNF in tau knockout mouse neurons.

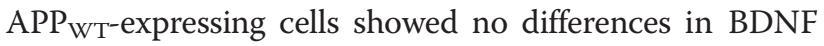
transport in axons compared to mock-transfectants (Fig. 6a, b). In contrast, $\mathrm{APP}_{\mathrm{OSK}^{-} \text {-expressing cells showed }}$ a significant decrease of anterograde, retrograde, and total axonal flux of BDNF, similar to wild-type neurons (Fig. 5).

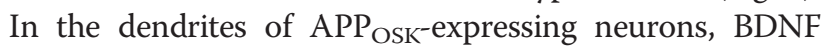
transport was also significantly reduced (Fig. 6c, d). Similar to the effects of eA $\beta O s[48,49]$, these results indicate that iA $\beta O s$ impair BDNF transport independent of tau.

\section{Axonal transport and dendritic distribution of mitochondria} are disrupted by $\mathrm{iABO}$

Mitochondria are essential for synaptic function as they provide ATP for synaptic transmission and contribute to local calcium buffering [13]. Because mitochondrial and BDNF transport are both microtubule-dependent, it is likely that mitochondrial transport is also affected by iA $\beta$ Os. To test this possibility, rat primary neurons were triply transfected with APP, Mt-eYFP, and BFP. Live imaging analysis revealed that bidirectional transport of mitochondria in axons was reduced in $\mathrm{APP}_{\mathrm{OSK}^{-}}$, but not $\mathrm{APP}_{\mathrm{WT}^{-}}$, expressing cells compared with mocktransfectants (Fig. 7a, b). In dendrites, mitochondria were evenly distributed along the dendritic shafts in mock-transfectants and $\mathrm{APP}_{\mathrm{WT}}$-expressing cells (Fig. 7c). In contrast, mitochondria in dendrites of $\mathrm{APP}_{\mathrm{OSK}^{-}} \mathrm{ex}-$ pressing cells were of shorter length and unevenly distributed, implying aberrant transport or a change in fission-fusion dynamics [50]. The latter finding may support our previous observation that mitochondrial network was fragmented in COS-7 cells expressing $\mathrm{APP}_{\mathrm{OSK}}$ [32]. These results indicate that the disruption of mitochondria transport may also contribute to the spine alterations observed in neurons accumulating $\mathrm{i} A \beta \mathrm{OS}$.

\section{Dendritic transport of TfR-labeled endosomes is impaired by iABOs}

Spine formation and growth requires membrane trafficking mediated by recycling endosomes [51]. Thus, we examined the effects of iA $\beta$ Os on the dendritic transport of recycling endosomes. Rat primary neurons were triply transfected with APP, TfR-GFP, and BFP. TfR is a marker protein localized to recycling endosomes. Live imaging analysis revealed that bidirectional transport of TfRpositive vesicles in dendrites was reduced in $\mathrm{APP}_{\mathrm{OSK}^{-}}$, but not $\mathrm{APP}_{\mathrm{WT}^{-}}$, expressing cells compared with mocktransfectants (Fig. 8). These results suggest that the impairment of recycling endosome transport may also contribute to the spine alteration caused by iAßOs.

\section{Discussion}

In the present study we showed that $\mathrm{iA} \beta \mathrm{O}$, generated by $\mathrm{APP}_{\mathrm{OSK}}$ expression in cultured neurons, impaired axonal
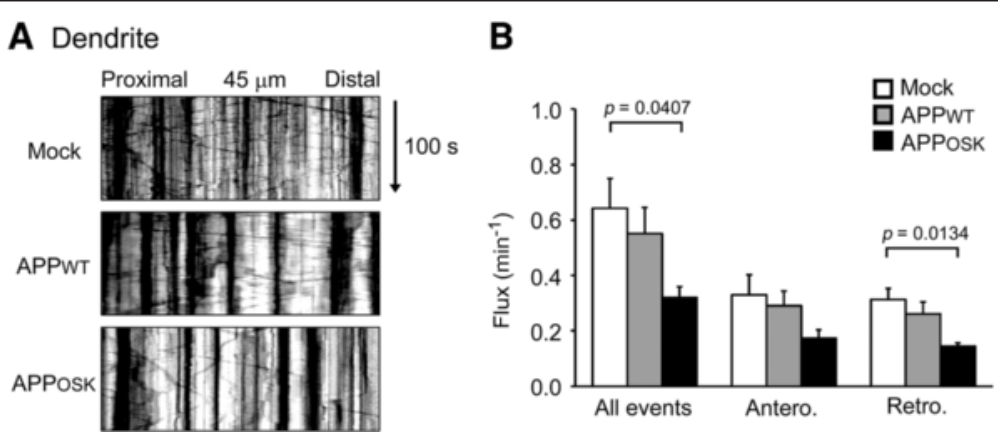

Fig. 8 Impaired dendritic transport of recycling endosomes in APPOsk-expressing neurons. Rat primary neurons were triply transfected with APP, TfRGFP, and BFP. a Transports of TfR in living neurons were recorded for $100 \mathrm{~s}$, and those in $45-\mu \mathrm{m}$ segments of the dendrite were analyzed. $\mathbf{b}$ Compared

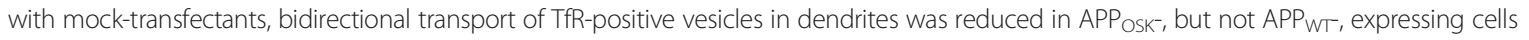


and dendritic transport of BDNF, mitochondria, and dendritic recycling endosomes (Figs. 5, 7 and 8). Because these cargoes are critical for spine formation and maintenance, reduced trafficking may have led to the observed decreases in spine density and in the number of mature mushroom spines (Fig. 2). Our results are significant because intraneuronal accumulation of $A \beta$ precedes its extracellular deposition in patients and $\mathrm{AD}$ model mice; thus, iA $\beta O s$ likely contribute to the early synaptic pathology in AD. Moreover, multiple lines of evidence demonstrate that trafficking defects are either an early cellular pathology or even causal in $\mathrm{AD}$ [52], underscoring the importance of defining $\mathrm{iA} \beta \mathrm{O}$ mechanisms of action.

$\mathrm{BDNF}$ transport defects in $\mathrm{APP}_{\mathrm{OSK}}$ neurons may reduce the amount of BDNF available for secretion, and in turn, compromise dendritic spine maturation and density. Spines are the primary site of excitatory input on neurons, and a reduced spine number and changes in morphology contribute to synaptic pathology in $\mathrm{AD}$. BDNF secreted from cells binds to and activates TrkB receptors that are located on both presynaptic axon terminals and postsynaptic dendritic spines of glutamatergic synapses [53]. BDNF-induced TrkB signaling modulates synaptic transmission by enhancing presynaptic glutamate release and increasing the open probability of postsynaptic NMDA receptor ion channel [53]. Increased NMDA receptor currents activate the Rac1 (Ras-related C3 botulinum toxin substrate 1) pathway and suppress cofilin, an actin-depolymerizing factor, thereby promoting spine growth and stabilization [54]. Thus, iA $\beta \mathrm{O}$-induced transport impairment may reduce the amount of BDNF available for secretion, leading to synaptic impairment and spine reduction.

We also found that iA $\beta O s$ impair transport of mitochondria and recycling endosomes, which are essential for spine development and maintenance. Mitochondria translocate to pre- and postsynaptic regions to supply ATP for neurotransmission [13]. A reduction in ATP availability may reduce presynaptic secretion of essential signaling molecules such as glutamate and BDNF, and thereby, as similarly described above, impair postsynaptic signaling of cascades such as $\mathrm{Ca}^{2+} /$ calmodulin-dependent protein kinase II (CaMKII) and Rac 1 that are required for spine maintenance [54-56]. A role for dendritic mitochondria is to buffer synaptic calcium; excess calcium may negatively regulate actin-binding proteins that are required for maintaining for spine density and plasticity (discussed below) $[12,57]$. Thus, perturbations in mitochondrial motility or morphology induced by iA $\beta$ Os likely diminish spine structure stemming from multiple mechanisms. Recycling endosomes also play an essential role in spine morphology. Elegant studies from the Ehlers laboratory demonstrated that active transport of recycling endosomes supplies necessary plasma membrane lipids and proteins required to support spine structure and function [51]. Taken together, iA $\beta \mathrm{O}$-induced intracellular transport disruption is likely an important contributor to mature spine loss in $\mathrm{APP}_{\mathrm{OSK}^{-}}$-expressing neurons.

iA $\beta$ Os may disrupt intracellular transport by perturbing motor function through second message cascades or by directly binding to motor proteins. eA $\beta \mathrm{O}$ binding to membrane targets results in changes in kinase and phosphatase activity leading to transport blockade of organelles, including mitochondria and BDNF-containing vesicles [9-11, 48, 58-60]. Similarly, organelle transport is reduced in squid axoplasm perfused with $A \beta O$ s via activation of casein kinase 2 [61], providing evidence that $\mathrm{iA} \beta \mathrm{Os}$ impinge on signaling cascades that reduce trafficking. It is likely that $\mathrm{APP}_{\mathrm{OSK}}$ dysregulates intracellular $\mathrm{Ca}^{2+}$ signaling via ER stress and mitochondrial damage [32] that may ultimately have negative consequences on the mechanisms that regulate transport. For example, mitochondria transport is governed by Miro-MiltonKinesin-I in a $\mathrm{Ca}^{2+}$-dependent mechanism, where $\mathrm{Ca}^{2+}$ binding to Miro inhibits Kinesin-I-based motility [62]. It is thus possible that the $\mathrm{APP}_{\mathrm{OSK}}$ effects on intracellular $\mathrm{Ca}^{2+}$ result in a blockade of mitochondria transport. Moreover, $\mathrm{Ca}^{2+}$ signaling may represent a general mechanism for the regulation of microtubule-based transport. The transport of dense core vesicles containing neuropeptides [63] and the dendritic kinesin, KIF17, ferrying the NR2B glutamate receptor subunit [64], are also subject to $\mathrm{Ca}^{2+}$ regulation, demonstrating that perturbations in $\mathrm{Ca}^{2+}$ homeostasis likely have broader effects on organelle trafficking. A second possible mechanism of transport disruption is the direct binding of $\mathrm{iA} \beta \mathrm{Os}$ or $\mathrm{A} \beta$ to motor proteins [65]. Ari et al. demonstrate mislocalization of NMDA receptors and NGF/NTR (p75) at the post-synaptic membrane due to intracellular $A \beta$ binding the mitotic kinesin Eg 5 [66].

Despite a plethora of recent reports, the role of tau in transport disruption is still a matter of debate. In vivo studies demonstrate that axonal transport is unaffected by tau overexpression or suppression, or by moderate amounts of hyperphosphorylated tau $[67,68]$. In primary culture, we have demonstrated that eA $\beta \mathrm{O}$-induced BDNF-transport disruption is independent of tau [48, 49]. However, other studies suggest that phospho-tau inhibits fast axonal transport (FAT) by interacting directly with motor-cargo complexes or initiating aberrant signaling cascades that alter FAT dynamics $[69,70]$, and that tau reduction prevents $\mathrm{A} \beta \mathrm{O}$-induced defects in mitochondria and neurotrophin receptor TrkA transport [10, 60]. It is possible that transport defects are motor and/or cargo dependent. For example, mitochondria are transported primarily by KIF5 whereas BDNF is transported primarily by KIF1A [71]. Kinesins may be differentially affected by hyperphosphorylated tau, thus, we cannot rule out that in 
our studies the reduction in mitochondria and endosome transport is tau-dependent. How $\mathrm{APP}_{\mathrm{OSK}}$ and tau influences organelle transport is a focus of ongoing studies.

Similar to the initiation of transport deficits, iA $\beta O$ induced signaling cascades may compromise dendritic spine maturation and density. Actin, a critical structural component of spines, is tightly regulated by actinbinding proteins and their associated kinases and phosphatases [72]. eA $\beta O s$ reduce spine density and alter morphology by at least two mechanisms: one is the mislocalization of p21-activated kinase (PAK), and another is the activation of the calcineurin, a calcium-dependent phosphatase implicated in AD. Changes in these signaling cascades alter the dynamics of actin-binding proteins needed to maintain and stabilize spine actin [73-75]. Through a yet unexplored mechanism, iA $\beta O$ s may also impinge on the regulation of actin-binding proteins that lead to spine retraction. Consistent with our previous findings for eA $\beta O$ s, we show that $\mathrm{iA} \beta \mathrm{O}$-induced BDNF transport defects and spine loss occur independent of tau. These effects are likely caused by signaling cascade activation, such as the calcineurin-GSK3 $\beta$ pathway, that persists in the absence of tau [48]. Because tau knockout mice do not exhibit any serious health or cognitive deficits, some researchers proposed that lowering endogenous tau is a beneficial treatment to protect neurons from $A \beta$ toxicity [76]. However, our results imply that such tau-reducing therapy would result in failure to prevent $\mathrm{A} \beta$-induced spine alteration.

Although $A \beta O$ s generated by the Osaka mutation are mostly intracellular, picomolar amounts are released from cells (ELISA data; this study). We found that extracellular wild-type $A \beta$ showed a trophic effect on synapses at physiological low concentrations; however, Osakamutant $A \beta$ showed no trophic effect on spines. Recent evidence suggests that endogenous $A \beta$ modulates synaptic plasticity $[40,41]$ and regulates neurotransmitter release probability [77]. These positive effects of $A \beta$ are observed at picomolar concentrations, and higher, nanomolar concentrations lead to toxicity. In cultured hippocampal slices, we previously observed that relatively low concentrations of wild-type $A \beta$ enhanced the levels of synaptophysin, whereas Osaka-mutant $A \beta$ did not [42]. In the present study, unlike wild-type $A \beta$, Osaka-mutant $A \beta$ did not show trophic effects on spines at the same low concentrations. The lack of such trophic actions may in part account for the synaptic alteration associated with $\mathrm{APP}_{\mathrm{OSK}}$.

\section{Conclusion}

In summary, we showed that $\mathrm{iA} \beta \mathrm{O}$ s reduce mature dendritic spines and block axonal and dendritic transport in primary neurons. Both the spine alteration and BDNF transport blockade are tau-independent.
iA $3 \mathrm{O}$-induced spine alterations may be caused by deregulating enzymes within dendritic spines and/or by reducing axonal and dendritic transport of organelles and proteins necessary for spine formation and maintenance. Furthermore, extracellular Osaka-mutant $A \beta$ lacks the trophic effect on spines, likely inflicting a dual assault on spines in AD. This work is significant because $\mathrm{i} A \beta O$ generation precedes extracellular $A \beta$ accumulation and these data will promote further investigation of $\mathrm{iA} \beta \mathrm{O}$ toxicity with the hope to develop therapeutic compounds for prevention and treatment of $\mathrm{AD}$.

\section{Abbreviations}

AD: Alzheimer's disease; AB: Amyloid $\beta$; APP: Amyloid precursor protein; eA $\beta O s$ : Extracellular $A \beta$ oligomers; $A \beta O$ S: Intracellular $A \beta$ oligomers; BDNF: Brain-derived neurotrophic factor; LTP: Long-term potentiation; LTD: Long-term depression; TfR: Transferrin receptor; EGFP: Enhanced green fluorescent protein; mRFP: Monomeric red fluorescent protein; eBFP: Enhanced blue fluorescent protein; EYFP: Enhanced yellow fluorescent protein; HBSS: Hank's balanced salt solution; Rac1: Ras-related C3 botulinum toxin substrate 1; FAT: Fast axonal transport.

\section{Competing interests}

The authors declare that they have no competing interests.

\section{Authors' contributions}

MAS and TT designed experiments. TU, EMR, MY, KN and MAS performed experiments and analyzed data. MAS and TT wrote the manuscript. All authors read and approved the final manuscript.

\section{Acknowledgements}

We thank Kenji Fukunaga, Atsushi Koyama, Reina Fujita, and Maiko Mori for technical assistance and Kathlyn Gan for critical comments on the manuscript. This study was supported by the Grants-in-Aid for Scientific Research from the Ministry of Education, Culture, Sports, Science and Technology of Japan (no. 23110514, 24659434, 25290018); by the Grantsin-Aid from the Ministry of Health, Labour, and Welfare, Japan; and in part by the Strategic Research Program for Brain Sciences (CREST), the Ministry of Education, Culture, Sports, Science and Technology of Japan, and the Canadian Institute for Health Research (no. 90396) to M.A.S. For initiating this work, M.A.S. thanks the Japanese Society for Promotion of Science Long-Term Invitation Fellowship (\#L11710).

\section{Author details}

'Department of Neuroscience, Osaka City University Graduate School of Medicine, 1-4-3 Asahimachi, Abeno-ku, Osaka 545-8585, Japan. ${ }^{2}$ Core Research for Evolutional Science and Technology, Japan Science and Technology Agency, Kawaguchi, Japan. ${ }^{3}$ Department of Biological Sciences, Simon Fraser University, Burnaby, British Columbia V5A 1S6, Canada. ${ }^{4}$ Department of Immunology, Osaka City University Graduate School of Medicine, Osaka, Japan. ${ }^{5}$ Department of Clinical Neuroscience, Osaka City University Medical School, Osaka, Japan.

Received: 3 July 2015 Accepted: 9 August 2015

Published online: 21 August 2015

\section{References}

1. Ferreira ST, Klein WL (2011) The A oligomer hypothesis for synapse failure and memory loss in Alzheimer's disease. Neurobiol Learn Mem 96:529-543. doi:10.1016/..nIm.2011.08.003

2. Tu S, Okamoto S, Lipton SA, Xu H (2014) Oligomeric Aß-induced synaptic dysfunction in Alzheimer's disease. Mol Neurodegener 9:48. do:10.1186/ 1750-1326-9-48

3. Lambert MP, Barlow AK, Chromy BA, Edwards C, Freed R, Liosatos M, Morgan TE, Rozovsky I, Trommer B, Viola KL, Wals P, Zhang C, Finch CE, Krafft GA, Klein WL (1998) Diffusible, nonfibrillar ligands derived 
from Abeta1-42 are potent central nervous system neurotoxins. Proc Natl Acad Sci U S A 95:6448-6453

4. Walsh DM, Klyubin I, Fadeeva JV, Cullen WK, Anwyl R, Wolfe MS, Rowan MJ, Selkoe DJ (2002) Naturally secreted oligomers of amyloid beta protein potently inhibit hippocampal long-term potentiation in vivo. Nature 416:535-539

5. Shankar GM, Li S, Mehta TH, Garcia-Munoz A, Shepardson NE, Smith I, Brett FM, Farrell MA, Rowan MJ, Lemere CA, Regan CM, Walsh DM, Sabatini BL, Selkoe DJ (2008) Amyloid-beta protein dimers isolated directly from Alzheimer's brains impair synaptic plasticity and memory. Nat Med 14:837-842. doi:10.1038/nm1782

6. Li S, Hong S, Shepardson NE, Walsh DM, Shankar GM, Selkoe D (2009) Soluble oligomers of amyloid Beta protein facilitate hippocampal long-term depression by disrupting neuronal glutamate uptake. Neuron 62:788-801. doi:10.1016/..neuron.2009.05.012

7. Lacor PN, Buniel MC, Furlow PW, Clemente AS, Velasco PT, Wood M, Viola KL, Klein WL (2007) Abeta oligomer-induced aberrations in synapse composition, shape, and density provide a molecular basis for loss of connectivity in Alzheimer's disease. J Neurosci 27:796-807

8. Shankar GM, Bloodgood BL, Townsend M, Walsh DM, Selkoe DJ, Sabatini BL (2007) Natural oligomers of the Alzheimer amyloid-beta protein induce reversible synapse loss by modulating an NMDA-type glutamate receptordependent signaling pathway. J Neurosci 27:2866-2875

9. Decker H, Lo KY, Unger SM, Ferreira ST, Silverman MA (2010) Amyloid-beta peptide oligomers disrupt axonal transport through an NMDA receptordependent mechanism that is mediated by glycogen synthase kinase 3beta in primary cultured hippocampal neurons. J Neurosci 30:9166-9171. doi:10.1523/JNEUROSCI.1074-10.2010

10. Vossel KA, Zhang K, Brodbeck J, Daub AC, Sharma P, Finkbeiner S, Cui B, Mucke $L$ (2010) Tau reduction prevents Abeta-induced defects in axonal transport. Science 330:198. doi:10.1126/science.1194653

11. Tang Y, Scott DA, Das U, Edland SD, Radomski K, Koo EH, Roy S (2012) Early and selective impairments in axonal transport kinetics of synaptic cargoes induced by soluble amyloid $\beta$-protein oligomers. Traffic 13:681-693. doi:10.1111/j.1600-0854.2012.01340.x

12. Li Z, Okamoto K, Hayashi Y, Sheng M (2004) The importance of dendritic mitochondria in the morphogenesis and plasticity of spines and synapses. Cell 119:873-887

13. Sheng ZH, Cai Q (2012) Mitochondrial transport in neurons: impact on synaptic homeostasis and neurodegeneration. Nat Rev Neurosci 13:77-93. doi:10.1038/nrn3156

14. Sheng ZH (2014) Mitochondrial trafficking and anchoring in neurons: New insight and implications. J Cell Biol 204:1087-1098. doi:10.1083/ jcb.201312123

15. Luine V, Frankfurt M (2012) Interactions between estradiol, BDNF and dendritic spines in promoting memory. Neuroscience 239:34-45. doi:10.1016/j.neuroscience.2012.10.019

16. Kellner Y, Gödecke N, Dierkes T, Thieme N, Zagrebelsky M, Korte M (2014) The BDNF effects on dendritic spines of mature hippocampal neurons depend on neuronal activity. Front Synaptic Neurosci 6:5. doi:10.3389/fnsyn.2014.00005

17. Scharfman HE, Chao MV (2013) The entorhinal cortex and neurotrophin signaling in Alzheimer's disease and other disorders. Cogn Neurosci 4:123-135. doi:10.1080/17588928.2013.826184

18. Khatri N, Man HY (2013) Synaptic activity and bioenergy homeostasis: implications in brain trauma and neurodegenerative diseases. Front Neurol 4:199. doi:10.3389/fneur.2013.00199

19. Gouras GK, Tsai J, Naslund J, Vincent B, Edgar M, Checler F, Greenfield JP, Haroutunian V, Buxbaum JD, Xu H, Greengard P, Relkin NR (2000) Intraneuronal Abeta42 accumulation in human brain. Am J Pathol 156:15-20

20. Wirths O, Multhaup G, Czech C, Blanchard V, Moussaoui S, Tremp G, Pradier L, Beyreuther K, Bayer TA (2001) Intraneuronal Abeta accumulation precedes plaque formation in beta-amyloid precursor protein and presenilin-1 double-transgenic mice. Neurosci Lett 306:116-120

21. Takahashi RH, Milner TA, Li F, Nam EE, Edgar MA, Yamaguchi H, Beal MF, Xu H, Greengard P, Gouras GK (2002) Intraneuronal Alzheimer abeta42 accumulates in multivesicular bodies and is associated with synaptic pathology. Am J Pathol 161:1869-1879

22. Oddo S, Caccamo A, Shepherd JD, Murphy MP, Golde TE, Kayed R, Metherate R, Mattson MP, Akbari Y, LaFerla FM (2003) Triple-transgenic model of Alzheimer's disease with plaques and tangles: intracellular Abeta and synaptic dysfunction. Neuron 39:409-421
23. Oddo S, Caccamo A, Smith IF, Green KN, LaFerla FM (2006) A dynamic relationship between intracellular and extracellular pools of Abeta. Am J Pathol 168:184-194

24. Knobloch M, Konietzko U, Krebs DC, Nitsch RM (2007) Intracellular Abeta and cognitive deficits precede beta-amyloid deposition in transgenic arcAbeta mice. Neurobiol Aging 28:1297-1306

25. Knobloch M, Farinelli M, Konietzko U, Nitsch RM, Mansuy IM (2007) Abeta oligomer-mediated long-term potentiation impairment involves protein phosphatase 1-dependent mechanisms. J Neurosci 27:7648-7653

26. Price KA, Varghese M, Sowa A, Yuk F, Brautigam H, Ehrlich ME, Dickstein DL (2014) Altered synaptic structure in the hippocampus in a mouse model of Alzheimer's disease with soluble amyloid- $\beta$ oligomers and no plaque pathology. Mol Neurodegener 9:41. doi:10.1186/1750-1326-9-41

27. Calkins MJ, Manczak M, Mao P, Shirendeb U, Reddy PH (2011) Impaired mitochondrial biogenesis, defective axonal transport of mitochondria, abnormal mitochondrial dynamics and synaptic degeneration in a mouse model of Alzheimer's disease. Hum Mol Genet 20:4515-4529. doi:10.1093/hmg/ddr381

28. Bloom GS (2014) Amyloid- $\beta$ and tau: the trigger and bullet in Alzheimer disease pathogenesis. JAMA Neurol 71:505-508. doi:10.1001/jamaneurol.2013.5847

29. Tomiyama $T$, Nagata $T$, Shimada $H$, Teraoka R, Fukushima A, Kanemitsu H, Takuma H, Kuwano R, Imagawa M, Ataka S, Wada Y, Yoshioka E, Nishizaki T, Watanabe Y, Mori H (2008) A new amyloid beta variant favoring oligomerization in Alzheimer's-type dementia. Ann Neurol 63:377-387. doi:10.1002/ana.21321

30. Nishitsuji K, Tomiyama T, Ishibashi K, Ito K, Teraoka R, Lambert MP, Klein WL, Mori H (2009) The E693Delta mutation in amyloid precursor protein increases intracellular accumulation of amyloid beta oligomers and causes endoplasmic reticulum stress-induced apoptosis in cultured cells. Am J Pathol 174:957-969. doi:10.2353/ajpath.2009.080480

31. Tomiyama T, Matsuyama S, Iso H, Umeda T, Takuma H, Ohnishi K, Ishibashi K, Teraoka R, Sakama N, Yamashita T, Nishitsuji K, Ito K, Shimada H, Lambert MP, Klein WL, Mori H (2010) A mouse model of amyloid beta oligomers: their contribution to synaptic alteration, abnormal tau phosphorylation, glial activation, and neuronal loss in vivo. J Neurosci 30:4845-4856. doi:10.1523/JNEUROSCI.5825-09.2010

32. Umeda T, Tomiyama T, Sakama N, Tanaka S, Lambert MP, Klein WL, Mori H (2011) Intraneuronal amyloid $\beta$ oligomers cause cell death via endoplasmic reticulum stress, endosomal/lysosomal leakage, and mitochondrial dysfunction in vivo. J Neurosci Res 89:1031-1042. doi:10.1002/jnr.22640

33. Kaech S, Banker G (2006) Culturing hippocampal neurons. Nat Protoc 1:2406-2415

34. Miranda CJ, Braun L, Jiang $Y$, Hester ME, Zhang L, Riolo M, Wang H, Rao M, Altura RA, Kaspar BK (2012) Aging brain microenvironment decreases hippocampal neurogenesis through Wnt-mediated survivin signaling. Aging Cell 11:542-552. doi:10.1111/j.1474-9726.2012.00816.x

35. Burack MA, Silverman MA, Banker $G$ (2000) The role of selective transport in neuronal protein sorting. Neuron 26:465-472

36. Peebles CL, Yoo J, Thwin MT, Palop JJ, Noebels JL, Finkbeiner S (2010) Arc regulates spine morphology and maintains network stability in vivo. Proc Natl Acad Sci U S A 107:18173-18178. doi:10.1073/pnas.1006546107

37. Swanger SA, Yao X, Gross C, Bassell GJ (2011) Automated 4D analysis of dendritic spine morphology: applications to stimulus-induced spine remodeling and pharmacological rescue in a disease model. Mol Brain 4:38. doi:10.1186/1756-6606-4-38

38. Kwinter DM, Lo K, Mafi P, Silverman MA (2009) Dynactin regulates bidirectional transport of dense-core vesicles in the axon and dendrites of cultured hippocampal neurons. Neuroscience 162:1001-1010. doi:10.1016/ j.neuroscience.2009.05.038

39. Bourne J, Harris KM (2007) Do thin spines learn to be mushroom spines that remember? Curr Opin Neurobiol 17:381-386

40. Puzzo D, Privitera L, Leznik E, Fà M, Staniszewski A, Palmeri A, Arancio O (2008) Picomolar amyloid-beta positively modulates synaptic plasticity and memory in hippocampus. J Neurosci 28:14537-14545. doi:10.1523/JNEUROSCI.2692-08.2008

41. Puzzo D, Privitera L, Fa' M, Staniszewski A, Hashimoto G, Aziz F, Sakurai M, Ribe EM, Troy CM, Mercken M, Jung SS, Palmeri A, Arancio O (2011) Endogenous amyloid- $\beta$ is necessary for hippocampal synaptic plasticity and memory. Ann Neurol 69:819-830. doi:10.1002/ana.22313 
42. Takuma H, Teraoka R, Mori H, Tomiyama T (2008) Amyloid-beta E22Delta variant induces synaptic alteration in mouse hippocampal slices. Neuroreport 19:615-619. doi:10.1097/WNR.0b013e3282fb78c4

43. Hardy J, Selkoe DJ (2002) The amyloid hypothesis of Alzheimer's disease: progress and problems on the road to therapeutics. Science 297:353-356

44. Ittner LM, Ke YD, Delerue F, Bi M, Gladbach A, van Eersel J, Wölfing H, Chieng BC, Christie MJ, Napier IA, Eckert A, Staufenbiel M, Hardeman E, Götz J (2010) Dendritic function of tau mediates amyloid-beta toxicity in Alzheimer's disease mouse models. Cell 142:387-397. doi:10.1016/j.cell.2010.06.036

45. Liao D, Miller EC, Teravskis PJ (2014) Tau acts as a mediator for Alzheimer's disease-related synaptic deficits. Eur J Neurosci 39:1202-1213. doi:10.1111/ejn.12504

46. Spires-Jones TL, Hyman BT (2014) The intersection of amyloid beta and tau at synapses in Alzheimer's disease. Neuron 82:756-771. doi:10.1016/ j.neuron.2014.05.004

47. Adachi N, Numakawa T, Richards M, Nakajima S, Kunugi H (2014) New insight in expression, transport, and secretion of brain-derived neurotrophic factor: Implications in brain-related diseases. World J Biol Chem 5:409-428. doi:10.4331/wjbc.v5.i4.409

48. Ramser EM, Gan KJ, Decker H, Fan EY, Suzuki MM, Ferreira ST, Silverman MA (2013) Amyloid- $\beta$ oligomers induce tau-independent disruption of BDNF axonal transport via calcineurin activation in cultured hippocampal neurons. Mol Biol Cell 24:2494-2505. doi:10.1091/mbc.E12-12-0858

49. Gan KJ, Silverman MA (2015) Dendritic and axonal mechanisms of $\mathrm{Ca}^{2+}$ elevation impair BDNF transport in A $\beta$ oligomer-treated hippocampal neurons. Mol Biol Cell 26:1058-1071. doi:10.1091/mbc.E14-12-1612

50. Itoh K, Nakamura K, lijima M, Sesaki H (2012) Mitochondrial dynamics in neurodegeneration. Trends Cell Biol 23:64-71. doi:10.1016/j.tcb.2012.10.006

51. Park M, Salgado JM, Ostroff L, Helton TD, Robinson CG, Harris KM, Ehlers MD (2006) Plasticity-induced growth of dendritic spines by exocytic trafficking from recycling endosomes. Neuron 52:817-830

52. Goldstein LS (2012) Axonal transport and neurodegenerative disease: can we see the elephant? Prog Neurobiol 99:186-190. doi:10.1016/ j.pneurobio.2012.03.006

53. Minichiello L (2009) TrkB signalling pathways in LTP and learning. Nat Rev Neurosci 10:850-860. doi:10.1038/nrn2738

54. Lai KO, Ip NY (2013) Structural plasticity of dendritic spines: the underlying mechanisms and its dysregulation in brain disorders. Biochim Biophys Acta 1832:2257-2263. doi:10.1016/j.bbadis.2013.08.012

55. Okamoto K, Bosch M, Hayashi Y (2009) The roles of CaMKII and F-actin in the structural plasticity of dendritic spines: a potential molecular identity of a synaptic tag? Physiology (Bethesda) 24:357-366. doi:10.1152/ physiol.00029.2009

56. Panja D, Bramham CR (2014) BDNF mechanisms in late LTP formation: A synthesis and breakdown. Neuropharmacology 76:664-676. doi:10.1016/j.neuropharm.2013.06.024

57. Saneyoshi T, Hayashi Y (2012) The Ca2+ and Rho GTPase signaling pathways underlying activity-dependent actin remodeling at dendritic spines. Cytoskeleton (Hoboken) 69:545-554. doi:10.1002/cm.21037

58. Rui $Y$, Tiwari $P$, Xie Z, Zheng JQ (2006) Acute impairment of mitochondrial trafficking by beta-amyloid peptides in hippocampal neurons. J Neurosci 26:10480-10487

59. Poon WW, Carlos AJ, Aguilar BL, Berchtold NC, Kawano CK, Zograbyan V, Yaopruke T, Shelanski M, Cotman CW (2013) B-Amyloid (Aß) oligomers impair brain-derived neurotrophic factor retrograde trafficking by down-regulating ubiquitin C-terminal hydrolase, UCH-L1. J Biol Chem 288:16937-16948. doi:10.1074/jbc.M113.463711

60. Vossel KA, Xu JC, Fomenko V, Miyamoto T, Suberbielle E, Knox JA, Ho K, Kim DH, Yu GQ, Mucke L (2015) Tau reduction prevents Aß-induced axonal transport deficits by blocking activation of GSK3 $\beta$. J Cell Biol 209:419-433. doi:10.1083/jcb.201407065

61. Pigino G, Morfini G, Atagi Y, Deshpande A, Yu C, Jungbauer L, LaDu M, Busciglio J, Brady S (2009) Disruption of fast axonal transport is a pathogenic mechanism for intraneuronal amyloid beta. Proc Natl Acad Sci U S A 106:5907-5912. doi:10.1073/pnas.0901229106

62. Schwarz TL (2013) Mitochondrial trafficking in neurons. Cold Spring Harb Perspect Biol 5:a011304. doi:10.1101/cshperspect.a011304

63. Shakiryanova D, Morimoto T, Zhou C, Chouhan AK, Sigrist SJ, Nose A, Macleod GT, Deitcher DL, Levitan ES (2011) Differential control of presynaptic CaMKII activation and translocation to active zones. J Neurosci 31:9093-9100. doi:10.1523/JNEUROSCI.0550-11.2011

64. Guillaud L, Wong R, Hirokawa N (2008) Disruption of KIF17-Mint1 interaction by CaMKII-dependent phosphorylation: a molecular model of kinesin-cargo release. Nat Cell Biol 10:19-29

65. Borysov SI, Granic A, Padmanabhan J, Walczak CE, Potter H (2011) Alzheimer $A \beta$ disrupts the mitotic spindle and directly inhibits mitotic microtubule motors. Cell Cycle 10:1397-1410

66. Ari C, Borysov SI, Wu J, Padmanabhan J, Potter H (2014) Alzheimer amyloid beta inhibition of Eg5/kinesin 5 reduces neurotrophin and/or transmitter receptor function. Neurobiol Aging 35:1839-1849. doi:10.1016/ j.neurobiolaging.2014.02.006

67. Yuan A, Kumar A, Peterhoff C, Duff K, Nixon RA (2008) Axonal transport rates in vivo are unaffected by tau deletion or overexpression in mice. J Neurosci 28:1682-1687. doi:10.1523/JNEUROSCI.5242-07.2008

68. Yuan A, Kumar A, Sasaki T, Duff K, Nixon RA (2013) Global axonal transport rates are unaltered in htau mice in vivo. J Alzheimers Dis 37:579-586. doi:10.3233/JAD-130671

69. LaPointe NE, Morfini G, Pigino G, Gaisina IN, Kozikowski AP, Binder LI, Brady ST (2009) The amino terminus of tau inhibits kinesin-dependent axona transport: implications for filament toxicity. J Neurosci Res 87:440-451. doi:10.1002/jnr.21850

70. Kanaan NM, Morfini GA, LaPointe NE, Pigino GF, Patterson KR, Song Y, Andreadis A, Fu Y, Brady ST, Binder LI (2011) Pathogenic forms of tau inhibit kinesin-dependent axonal transport through a mechanism involving activation of axonal phosphotransferases. J Neurosci 31:9858-9868. doi:10.1523/JNEUROSCI.0560-11.2011

71. Maday S, Twelvetrees AE, Moughamian AJ, Holzbaur EL (2014) Axonal transport: cargo-specific mechanisms of motility and regulation. Neuron 84:292-309. doi:10.1016/j.neuron.2014.10.019

72. Shirao T, González-Billault C (2013) Actin filaments and microtubules in dendritic spines. J Neurochem 126:155-164. doi:10.1111/jnc.12313

73. Ma QL, Yang F, Calon F, Ubeda OJ, Hansen JE, Weisbart RH, Beech W, Frautschy SA, Cole GM (2008) p21-activated kinase-aberrant activation and translocation in Alzheimer disease pathogenesis. J Biol Chem 283:14132-14143. doi:10.1074/jbc.M708034200

74. Wu HY, Hudry E, Hashimoto T, Uemura K, Fan ZY, Berezovska O, Grosskreutz CL, Bacskai BJ, Hyman BT (2012) Distinct dendritic spine and nuclear phases of calcineurin activation after exposure to amyloid- $\beta$ revealed by a novel fluorescence resonance energy transfer assay. J Neurosci 32:5298-5309. doi:10.1523/JNEUROSCI.0227-12.2012

75. Henriques AG, Oliveira JM, Carvalho LP, da Cruz E Silva OA (2014) A Influences Cytoskeletal Signaling Cascades with Consequences to Alzheimer's Disease. Mol Neurobiol [Epub ahead of print]. doi: 10.1007/s12035-014-8913-4

76. Roberson ED, Scearce-Levie K, Palop JJ, Yan F, Cheng IH, Wu T, Gerstein H, Yu GQ, Mucke L (2007) Reducing endogenous tau ameliorates amyloid beta-induced deficits in an Alzheimer's disease mouse model. Science 316:750-754

77. Abramov E, Dolev I, Fogel H, Ciccotosto GD, Ruff E, Slutsky I (2009) Amyloidbeta as a positive endogenous regulator of release probability at hippocampal synapses. Nat Neurosci 12:1567-1576. doi:10.1038/nn.2433

\section{Submit your next manuscript to BioMed Central and take full advantage of:}

- Convenient online submission

- Thorough peer review

- No space constraints or color figure charges

- Immediate publication on acceptance

- Inclusion in PubMed, CAS, Scopus and Google Scholar

- Research which is freely available for redistribution 